\title{
Effectiveness of predicting outcome in septic shock in critically ill children by assessing serum lactate levels
}

\author{
Choudhury $\mathbf{J}^{1}$, Routray $\mathbf{S S}^{2}$ \\ ${ }^{1}$ Dr. Jasashree Choudhury, Associate Professor, Department of Pediatrics, IMS \& SUM Hospital, BBSR, ${ }^{2}$ Dr. Sidharth \\ Sraban Routray, Assistant Professor, Department of Anaesthesiology and Critical Care, SCB Medical College \& \\ Hospital, Cuttack, Odisha, India.
}

Address for Correspondence: Dr. Jasashree Choudhury, Assoc. Prof., E-mail: drjasashree@gmail.com

\begin{abstract}
Background and Aims: Hyperlactatemia at the time of admission is a documented risk factor for mortality in critically ill adult patients. However, the significance of lactate measurement at admission for mortality in critically ill children remains uncertain. This study evaluated the predictive value of blood lactate levels at the time of admission and determined the cut-off values for predicting in-hospital mortality in the critically ill children. Materials and Methods: A total of 60 children with diagnosis of sepsis admitted to PICU of a tertiary care hospital were included in the study. PRISM III score and demographic characteristics of all children were recorded. Serum lactate levels were measured at 03, 12 and 24 h of PICU admission. The outcome like survival or death was correlated with serum lactate levels. Results: Septic shock was the most common type of shock and had highest mortality. Lactate levels were significantly higher in non survivors in comparison to survivors. A lactate value of more than $5 \mathrm{mmol} / 1$ at $0-3,12$ and $24 \mathrm{~h}$ of PICU admission had increased mortality. Conclusions: A high blood lactate level at admission is independently associated with higher inhospital mortality in the critically ill children.
\end{abstract}

Keywords: Lactate Level, Pediatric, PRISM III Score, Septic Shock.

\section{Introduction}

Septic shock is the most common life-threatening condition encountered in children worldwide [1]. The management of pediatric septic shock patients includes not only early recognition of inadequate tissue perfusion but also timely correction to prevent anaerobic metabolism, metabolic acidosis and cellular death [2]. Hyperlactatemia is a cardinal finding of septic shock which is resulting from tissue hypoxia [3].

Hyperlactatemia is defined as lactate levels between 18 to $45 \mathrm{mg} / \mathrm{dl}$ whereas lactic acidosis is defined as lactate levels more than $45 \mathrm{mg} / \mathrm{dl}$ and $\mathrm{pH}$ below 7.35 [4]. Increased lactate levels may be considered an early marker of a potentially reversible stage of early septic shock [5]. There are few studies on lactate levels in the pediatric age group with sepsis/septic shock. In neonates, studies have shown a poor correlation between $\mathrm{pH}$ and blood lactate concentration [6].

Manuscript received: $15^{\text {th }}$ Dec 2015

Reviewed: $26^{\text {th }}$ Dec 2015

Author Corrected; $30^{\text {th }}$ Dec 2015

Accepted for Publication: $19^{\text {th }}$ Jan 2016
In preterm newborns, hyperlactatemia has been described as an indicator of sepsis, but the predictive value for the outcome is not clear [7]. In pediatric sepsis/septic shock, significance of serum lactate is controversial. The present study was conducted with an aim to measure serial lactate levels in children with septic shock and correlates these levels with the outcome.

\section{Material and Method}

It was a prospective observational study conducted in PICU of a tertiary care centre of Bhubaneswar, Odisha, India. Sixty cases of septic shock between the ages of 1 month and 12 years were enrolled prospectively in our study over a period of 1 year.

Septic shock was defined as sepsis with either hypotension, i.e. systolic $\mathrm{BP}<2 \mathrm{SD}$ adjusted for age or at least one manifestation of inadequate organ perfusion, i.e., (1) altered mentation (2) hypoxia $\left(\mathrm{PaO}_{2}\right.$ $<45 \mathrm{mmHg}$ while breathing room air (3) metabolic 
acidosis (4) Oliguria along with signs of poor peripheral perfusion. Sepsis was defined as the presence of more than two of the following findings: (1) temperature $>38^{\circ} \mathrm{C}$ or $<36^{\circ} \mathrm{C}$, (2) WBC count $>15,000$ cells $/ \mathrm{mm}^{3},<4000$ cells $/ \mathrm{mm}^{3}$, or $10 \%$ immature neutrophils and (3) increased acute phase reactants (i.e., $\mathrm{ESR}>20 \mathrm{~mm} / \mathrm{h}$ or $\mathrm{CRP}>20 \mathrm{mg} / \mathrm{l})$.

A positive blood culture for a likely pathogen or bacterial culture from an otherwise sterile site was not necessary for diagnosis of sepsis [8]

Patients excluded from the study were: (1) patients with shock, due to cardiogenic, oligemic, anaphylactic, neurogenic shock (2) patients with known malignancies and on immunosuppressive therapy (3) patients with serious neurological disease, chronic illness and major congenital malformations, and (4) postoperative cases.

Following clinical data were recorded for all patients: age/sex, underlying infection, PRISM III score $[9,10]$ and need for mechanical ventilation. All patients were monitored for vital parameters, Glasgow Coma Scale (GCS), urine output and central venous pressure.

Arterial blood gas (ABG) analysis was done at 0-3, 12, $24,48 \mathrm{~h}$, and as and when required.

The serum lactate level was measured in arterial blood at 0-3 hrs (lactate 1), $12 \mathrm{hrs}$ (lactate 2) and $24 \mathrm{hrs}$ (lactate 3). Treatment of septic shock was done in all patients as per guidelines [11]. The outcome of patients was recorded as "survived" or "expired". Serial serum lactate levels were measured and compared between survivors and non-survivors.

Statistical methods: Statistical analysis was performed using the Windows SPSS software version 16. The continuous variables with normal distribution were expressed as mean $\pm \mathrm{SD}$ and were compared using Student's t-test.

The continuous variables with an asymmetric distribution were expressed as median and the respective range interval were compared using the nonparametric Mann-Whitney test.

\section{Result}

Different characteristics of patients admitted in PICU with septic shock are shown in [Table-1]. Pneumonia (70\%) was the most common infection associated with septic shock. 0nly 10\% patients had culture positive sepsis.

Table - 1: Characteristics of patients admitted in PICU with septic shock.

\begin{tabular}{|l|c|c|}
\hline \multicolumn{2}{|l|}{ Characteristics } & Value \\
\hline Number of patients included in the study & & $1: 2$ \\
\hline Male : female & Mean [months] & $16.4 \pm 35.8$ \\
\hline Age & $1-6$ months & $42(70 \%)$ \\
\hline Age group & $6-12$ months & $12(20 \%)$ \\
& $12-144$ months & $6(10 \%)$ \\
\hline Underlying Infective Pathology & Pneumonia & $42(70 \%)$ \\
\hline & Empyema & $6(10 \%)$ \\
\hline
\end{tabular}

Table-2 Shows age, sex, total leucocyte counts, GCS and blood $\mathrm{pH}$ at the time of transfer to PICU. There were no significant difference between survivors and non-survivors. All three lactate levels and PRISM III score were significantly higher in non-survivors as compared to survivors. 
Table-2: Various clinical parameters, PRISM III scores, and lactate levels among survivor and non-survivors.

\begin{tabular}{|c|c|c|c|}
\hline Variable & Survivors & Non-survivors & P-value \\
\hline $\begin{array}{l}\text { Age Mean (months) } \\
\text { Median [months (IQR)] }\end{array}$ & $\begin{array}{c}24.4 \pm 43.1 \\
5(3.8) \\
\end{array}$ & $\begin{array}{c}11.5 \pm 26.4 \\
6(3.9) \\
\end{array}$ & $\begin{array}{l}0.601 \\
0.875\end{array}$ \\
\hline Male : Female & $9: 6$ & $5: 8$ & 0.511 \\
\hline GCS at PICU arrival (mean) & $9.6 \pm 2.24$ & $8.16 \pm 2.9$ & 0.124 \\
\hline TLC (mean) & $17,200 \pm 4340$ & $18,100 \pm 5450$ & 0.690 \\
\hline PH at transfer to PICU (mean) & $7.32 \pm 0.15$ & $7.25 \pm 0.14$ & 0.504 \\
\hline PRISM III score (mean) & $9.3 \pm 4.9$ & $22.18 \pm 6.95$ & 0.001 \\
\hline Lactate 1 (mean; mg/dl) & $41.7 \pm 18.7$ & $79.8 \pm 67.42$ & 0.029 \\
\hline Lactate 2 (mean; $\mathrm{mg} / \mathrm{dl})$ & $39.2 \pm 29.6$ & $80.35 \pm 40.73$ & 0.004 \\
\hline Lactate 3 (mean; $\mathrm{mg} / \mathrm{dl}$ ) & $35.7 \pm 27.4$ & $77.85 \pm 48.86$ & 0.016 \\
\hline
\end{tabular}

The relationship of lactate at admission (lactate 1) with the PRISM III score was determined by calculating the spearman correlation coefficient and two tailed significance. A highly significant positive correlation existed between the PRISM III score and lactate level (lactate I) at the time of admission.

\section{Discussion}

In our study, all three lactate levels were significantly higher among nonsurvivors in comparison to survivors. Lactate value more than $45 \mathrm{mg} / \mathrm{dl}(5 \mathrm{mmol} / \mathrm{l})$ predicted death at a significant level. In previous studies by Duke et al [12] and Koliski et al[13] a lactate level of $>3$ $\mathrm{mmol} / 1$ significantly predicted mortality. This value was high $(5 \mathrm{mmol} / \mathrm{l})$ in our study.

In a study by Jacobs et al, meningitis was the most frequent infection occurring in $49.7 \%$ of cases [14]. Llorens et al. observed $24 \%$ cases of septic shock with no identifiable cause of infection.[1].

Higher mortality in our study is due to the fact that the majority of septic shock patients admitted to PICU were refractory to fluid and single inotrope. In infants, the incidence of sepsis and associated mortality is higher [15]. Most of patients in our study were infants thus resulting in high mortality.

Trials have demonstrated the prognostic value of lactate levels in postcardiac surgery patients, surgical patients, in infections/sepsis and septic shock [16]. Marecaux et al. showed that lactate is a better prognostic value that the tumor necrosis factor and IL-6 [17].

Lactate clearance can be used for risk stratification of patients and determine their response to therapy [18]. Vincent et al. described that shock patients with lower lactate value has the better prognosis [19].

Our study authenticates previous studies showing higher lactate level at the time of admission correlates with higher mortality.

\section{Conclusion}

Septic shock is a common cause for admission to intensive care unit with high mortality. The present study showed that most patients who died, had higher blood lactate levels than those who survived. Lactate levels at 0-3,12 and $24 \mathrm{~h}(>5 \mathrm{mmol} / \mathrm{l})$ and PRISM III score $(>10)$ were important predictors of death in septic shock.

There is a need for larger studies to find out the cut-off values of lactate levels above which morality increase significantly. Moreover high serum lactate level was associated with higher mortality.

Serum lactate can be used for prognostication of patients in sepsis or septic shock. This makes it useful as a prognostic marker of sepsis or septic shock patients.

\section{References}

1. Lloreins XS, Vargas S, Guerra F, Coronado L. Application of new sepsis definitions to evaluate outcome of pediatric patients with severe systemic infections. Pediatr Infect Dis J 1996;14:227-61.

2. Carcillo JA, Fields AI. Task force Committee Members, Clinical Practice parameters for hemodynamic support of pediatric and neonatal patients in septic shock. Crit care Med 2002;30:1365-78.

3. Mizock BA. The hepatosplanchnic area and hyperlacatatemia: A tale of two lactates. Crit care Med 2001;29:442-59. 
4. Stacpolle PW. Lactic acidosis. Endocrinol Metabol Clin North Am 1993;22:221-45.

5. Valenza F, Aletti G, Fossali T, Chevallard G, Sacconi $\mathrm{F}$, Irace $\mathrm{M}$, et al. Lactate as a marker of energy failure in critically ill patients: Hypothesis. Critical Care 2005;9:588-93.

6. Deshpande SA, Ward-Platt MP. Association between blood lactate and acid-base status and mortality in ventilated babies. Arch Dis Child Fetal Neonatal Ed 1997;76:F15-20.

7. Fitzgerald MJ, Gota M, Myers TF, Zeller WP. Early metabolic effects of sepsis in the preterm infant: Lactic acidosis and increased glucose requirement. J Pediatr 1992;121:951-5.

8. RPhillipDellinger, MitchelMLevy,Andrew Roads, SurvivingSepsis Campaign.International Guideline for Management of Severe sepsis and Setic shock 2012

9. R N Taori,Keya R,S Tullu Performance of PRISM(pediatric risk of mortality) score and PIM (pediatric risk of mortality) score in tertiary care pediatric ICU. Indian journal of pediatrics,vol$77, \operatorname{mar} 2010$

10. Pollack MM, Patel KM, Ruttimann UE. PRISM III: An updated pediatric risk of mortality score. Crit Care Med 1996;24:743-52.

11. Dellinger RP, Levy MM, Carlet JM, Bion J, Parker MM, Jaeschke R et al. Survivings Sepsis Campaign: International guidelines for management of severe sepsis and septic shock: 2008. Crit Care Med 2008;36:296-327.
12. Duke TD, Butt W, South M. Predictors of mortality and multiple organ failure in children with sepsis. Intensive Care Med 1997;23:684-92.

13. Hatherill M, Mclntyre AG, Wattie M, Murdoch AI. Early hyperlactatemia in critically ill children. Intensive Care Med 2000;26:314-8.

14. Jacobs RF, Sowell MK, Moss MM. Septic shock in children: Bacterial etiologies and temporal relationship. Pediatr Infect Dis J 1990;9:196-200.

15. Carcillo JA, David AL, Zaritsky A. Role of early fluid resuscitation in pediatric septic shock. JAMA 1991;266:1242-5.

16. Mikkelsen ME, Miltiades AN, Gaieski DF, Goyal M, Funhs BD, Shah CV, et al. Serum lactate is associated with mortality in sever sepsis independent of organ failure and shoc. Crit Care Med 2009;37:1670-7.

17. Bernardin G, Pradier C, Tiger F, Deloffre P, Mattei M. Blood pressure and arterial lactate level are early indicators of short term survival in human septic shock. Intensive Care Med 1996;22:17-25.

18. Marecaux G, Pinsky MR, Dupont E, Kahn RJ, Vincent JL. Blood lactate levels are better prognostic indicators than TNF and IL-6 levels in patient with septic shock. Intensive Care Med 1996;22:404-8.

19. Nguyen HB, Rivers EP, Knoblich BP, Jacobsen G, Muzzin A, Ressler JA, et al. Early lactate clearance is associated with improved outcome is severe sepsis and septic shock. Crit Care Med 2004;32:1637-42.

\section{How to cite this article?}

Choudhury J, Routray SS. Effectiveness of predicting outcome in septic shock in critically ill children by assessing serum lactate levels.Pediatr Rev: Int J Pediatr Res 2016;3(1):9-12.doi:10.17511/ijpr.2016.i01.03. 